\title{
Proses Berpikir Mahasiswa PendidikanInformatika dalam Menyelesaikan Soal- Soal Turunan Fungsi Ditinjau dari Perbedaan Kepribadian Dan Perbedaan Kemampuan Matematika
}

\author{
Muchamad Arif ${ }^{1}$ \\ ${ }^{1}$ Jurusan Pendidikan Informatika \\ Universitas Trunojoyo Madura \\ Madura, Indonesia \\ Muchamadarif83@yahoo.com
}

\begin{abstract}
ABSTRAK
Proses berpikir adalah aktivitas mental yang dimulai dari proses penerimaan , pengolahan, penyimpulan dan pemanggilan kembali informasi dari ingatan siswa.. Dalam penelitian ini untuk mengukur aktivitas mental seseorang dilakukan dengan cara wawancara secara mendalam terhadap tes yang dikerjakan oleh siswa. Dengan wawancara kita bisa mengetahui proses berpikir siswa dalam menyelesaikan soal-soal turunan fungsi ditinjau dari perbedaan kepribadian dan perbedaan kemampuan matematika. Proses berpikir dalam penelitian ini dibedakan menjadi dua yaitu tipe proses berpikir predikatif dan tipe proses berpikir fungsional. Proses berpikir predikatif lebih cenderung untuk melihat hubungan antara dua konsep atau lebih dalam pengambilan keputusan. Rendahkan proses berfikir fungsional lebih menitikberatkan untuk melihat mata rantai dan cara melaksanakan keputusan.Berdasar analisis data diperoleh hasil yaitu siswa yang berkepribadian introvert dengan kemampuan matematika tinggi memiliki tipe proses berpikir predikatif, siswa yang berkepribadian introvert dengan kemampuan matematika rendah memiliki tipe proses berpikir fungsional, siswa yang berkepribadian ekstrovert dengan kemampuan matematika tinggi memiliki tipe proses berpikir predikatif dan siswa yang berkepribadian ekstrovert dengan kemampuan matematika rendah memiliki tipe proses berpikir fungsional.

Kata kunci: Proses Berpikir, Berpikir Predikatif, Berpikir Fungsonal, Introvert, Extrovert ABSTRACT

Thinking process is mentality activity which is started from acceptance process, management, conclusion and recalling information from student memory.In this research to measure someone's mentality activity, is done by interviewing deeply toward test which has been done by the students. By doing that we know the students thinking process in answering the question. The thinking process in this research is divided into two types namely: Predicative Thinking Process and Functional Thinking Process. The first is tend to see correlation between two or more concepts in getting decision while functional thinking process is more focused to seethe core chain and the way to undertake decision. The subject in this research are four students. They are student with introvert personality who is highly skill in mathematics, student with introvert personality who is low skill in mathematics, student with extrovert personality who is highly skill in mathematics, and student with extrovert personality who is low skill in mathematics. The data which is obtained from the subjects is analyses by following activity process which happened simultaneously namely data reduction, data serving and conclusion making. In doing data analysis, something that should be principal is the main criterion from each thinking process (Predicative thinking process and functional thinking process)
\end{abstract}

Key word: Thinking Process, Predicative Thinking, Functional Thinking, Introvert y, Extrovert y. 


\section{PENDAHULUAN}

Ilmu matematika selalu berkaitan dengan ilmu-ilmu yang lain, salah satunya adalah Informatika. Dalam memahami Ilmu Informatika, mahasiswa diharuskan menguasai konsep dan dasar matematika yang kuat. Karena pada dasarnya ilmu Informatika sebagian besar kajiannya adalah penerapan dari Ilmu Matematika. Dilihat dari kurikulum Pendidikan Informatika, hampir sebagian besar memuat mata kuliah yang berkaitan dengan matematika antara lain kalkulus, aljabar linier,statistik, matematika diskrit dan masih banyak yang lainnya.

Sebagai seorang mahasiswa, salah satu potensi penting yang harus dikembangkan adalah berpikir. Suatu potensi yang perlu ditumbuhkembangkan secara tepat dan bertahap, meningkat ke arah yang bermanfaat untuk menghadapi hidup masa depannya. (Soedjadi, 2002:21). Karena ilmu yang dimiliki selama proses perkuliahan akan menjadi modal utama dalam melanjutkan perjuangan yang sebenarnya yaitu kehidupan bermasyarakatTurunan fungsi yang dipelajari di mata kuliah matematika 1 secara umum terdiri dari empat bagian yaitu turunan perpangkatan, turunan dalam bentuk perkalian fungsi, turunan dalam bentuk pembagian fungsi dan turunan dengan menggunakan aturan rantai. Sebenarnya materi ini sudah diberikan ketika mereka duduk di bangku SMA, namun berdasarkan pengalaman penulis mengajar seringkali mahasiswa dalam mengerjakan soal turunan fungsi cenderung langsung menurunkan fungsi tersebut tanpa melihat hubungannya dengan konsep yang lain dan biasanya hasil akhir yang mereka peroleh tidak dalam bentuk yang paling sederhana. Hal ini mungkin diakibatkan mereka kurang paham konsep-konsep materi yang lainnya.
Proses berpikir mahasiswa dalam menyelesaikan soal matematika secara umum bisa dikatakan berbeda-beda. Salah satunya disebabkan oleh perbedaan kepribadian yang dimiliki oleh masingmasing mahasiswa tersebut. Secara psikologis tipe kepribadian manusia ada dua jenis yaitu introvert dan ekstrovert. Orang yang mempunyai kepribadian introvert cenderung pendiam dan lebih menyukai dunianya sendiri. Hal ini tentunya kita sering temukan ketika kita mengajar di kelas, meskipun jumlahnya tidak terlalu banyak. Sehingga pada umumnya orang introvert dalam menyelesaikan sesuatu lebih hati-hati dan teliti. Sedangkan orang yang mempunyai kepribadian ekstrovert cenderung aktif, periang dan suka bergaul dengan temantemanya. Mereka lebih suka bersosialisasi dengan banyak orang dan cenderung lebih peka melihat keadaan. Dalam mengerjakan sesuatu orang ekstrovert biasanya lebih cepat meskipun tidak sempurna dan kadang-kadang ceroboh.

Berdasarkan perbedaan yang bertolak belakang antara ekstrovert dan introvert tersebut penulis menduga ada perbedaan proses berpikir mahasiswa dalam meyelesaikan soal-soal matematika khususnya turunan fungsi.

Selain itu perbedaan proses berpikir bisa ditinjau dari perbedaan kemampuan matematika yang dimiliki oleh setiap mahasiswa. Mahasiswa dengan kemampuan menengah ke atas biasanya cenderung menyelesaikan suatu soal secara ringkas dan cepat. Sedangkan mahasiswa dengan kemampuan yang rendah mempunyai kecenderungan mengikuti aturan-aturan atau konsep yang telah dijelaskan oleh seorang dosen. Hal ini terjadi dikarenakan mahasiswa takut mengalami kesalahan dalam mengerjakan soal yang ada apabila tidak mengikuti semua aturan atau konsep yang telah diajarkan oleh dosen. Selain karena 
perbedaan kepribadian dan kemampuan matematika, objek matematika yang abstrak memberi andil dalam proses berpikir mahasiswa.

Hasil penelitian Marpaung (1986:35) menunjukan bahwa struktur kognitif dalam mempelajari alogritma yang mengarahkannya untuk memiliki strategi tertentu dalam mempelajari atau menemukan konsep matematis dibangun dari elemen-elemen dasar yaitu proses berpikir tipe predikatif dan proses berpikir tipe fungsional. Proses berpikir tipe predikatif cenderung untuk melihat hubungan antara diantara dua konsep atau lebih dalam pengambilan keputusan. Sedangkan proses berpikir tipe fungsional lebih menitikberatkan untuk melihat mata rantai dan cara melaksanakan keputusan.

\section{METODE PENELITIAN}

Penelitian ini bertujuan untuk mendeskripsikan proses berpikir mahasiswa pendidikan informatikadalam menyelesaikan soal-soal turunan fungsi ditinjau dari perbedaaan kepribadian dan perbedaan kemampuan matematika. Berdasarkan hal tersebut penelitian ini dikategorikan penelitian deskriptif kualitatif. Sunarto (1994: 56) menyatakan bahwa tujuan dari penelitian deskriptif adalah mendeskripsikan fakta atau karakteristik suatu populasi secara sistematis, faktual dan akurat.

Penelitian ini menggunakan data kualitatif dan dideskripsikan untuk menghasilkan gambaran yang mendalam serta terperinci tentang proses berpikir mahasiswa dalam menyelesaikan soal-soal turunan fungsi. Untuk selanjutnya berdasarkan data tersebut proses berpikir mahasiswa akan dibedakan menjadi dua tipe proses berpikir yaitu tipe proses berpikir predikatif dan tipe proses berpikir fungsional berdasarkan ciri-ciri atau karakteristik yang muncul selama penelitian.
Analisis data dilaksanakan selama dan sesudah pengumpulan data. Adapun langkah-langkah yang harus ditempuh dalam analisis data (Miles dan Huberman, 1992) adalah sebagai berikut:

1. Tahap Reduksi Data

Dalam tahap reduksi data, kegiatan yang dilakukan adalah menyeleksi, menyederhanakan, mengelompokkan, mengabstraksikan serta memformulasikan semua data yang diperoleh dari hasil tes, wawancara, serta catatan-catatan pengamatan selama wawancara. Semua data dipilih sesuai dengan kebutuhan untuk menjawab pertanyaan penelitian.

2. Tahap Penyajian Data

Dalam tahap penyajian data kegiatan yang dilakukan adalah kegiatan yang berkaitan dengan tahap penulisan data yang sudah terorganisir, sehingga mudah untuk menafsirkan, memberi makna dan pengertiannya. Penyajian data dari penelitian ini adalah proses berpikir mahasiswa dalam menyelesaikan setiap soal.

3. Tahap Penarikan Kesimpulan

Berdasarkan penyajian data, selanjutnya dilakukan penarikan simpulan tentang proses berpikir mahasiswa ditinjau dari perbedaan kepribadian dan perbedaan kemampuan matematika dalam menyelesaikan soal-soal turunan fungsi - Dalam tahap penarikan kesimpulan kegiatan yang dilakukan adalah penarikan kesimpulan dari semua data yang diperoleh dari hasil tes dan wawancara. Selanjutkan akan didapatkan data kecenderungan proses berpikir mahasiswa apakah predikatif atau fungsional.

HASIL DAN PEMBAHASAN 
1. Hasil Tes

Berdasarkan hasil tes diketahui bahwa,mahasiswa yang berkepribadian introvert sebanyak 9 mahasiswa sedangkan mahasiswa yang berkepribadian ekstrovert sebanyak 26 mahasiswa. Hal ini sesuai dengan kajian pustaka di bab II, bahwa manusia berkepribadian eksrovert lebih banyak daripada manusia yang berkepribadian ekstrovert.Sekitar $75 \%$ manusia dimuka bumi ini yang berkepribadian ekstrovert dan $25 \%$ yang berkepribadian introvert.Dari table juga terlihat bahwa meskipun mahasiswa tersebut berkepribadian introvert atapun ekstrovert namun tidak ada seorangpun yang berkepribadian introvert sejati atau ekstrovert sejati artinya skor untuk kepribadian introvert ataupun ekstrovert maksimal (20) dan yang kebalikannya skornya minimal (0), pada umumnya mahasiswa yang berkepribadian ektrovert juga masih memiliki ciri-ciri kepribadian introvert dan sebaliknya demikian

2. Analisis

a. Analisis subjek pertama Table 1 Proses berpikir subjek S1

\begin{tabular}{|c|c|c|c|c|c|}
\hline \multicolumn{2}{|c|}{} & \multicolumn{5}{c|}{ Nomor Soal } \\
\cline { 2 - 6 } \multicolumn{2}{|c|}{} & 1 & 2 & 3 & 4 \\
\hline \multirow{4}{*}{ P1 1 P11 } & $\sqrt{ }$ & $\sqrt{ }$ & $\sqrt{ }$ & - \\
\cline { 2 - 6 } & P12 & $\sqrt{ }$ & & $\sqrt{ }$ & - \\
\cline { 2 - 6 } & P13 & $\sqrt{ }$ & $\sqrt{ }$ & $\sqrt{ }$ & - \\
\cline { 2 - 6 } & P14 & $\sqrt{ }$ & $\sqrt{ }$ & $\sqrt{ }$ & $\sqrt{ }$ \\
\hline \multirow{4}{*}{ F1 } & F11 & - & - & - & $\sqrt{ }$ \\
\cline { 2 - 6 } & F12 & - & - & - & $\sqrt{ }$ \\
\cline { 2 - 6 } & F13 & - & - & - & $\sqrt{ }$ \\
\cline { 2 - 6 } & F14 & - & - & - & - \\
\hline \multirow{2}{*}{$\begin{array}{c}\text { Kesimpu } \\
\text { lan }\end{array}$} & $\begin{array}{c}\text { Pre } \\
\text { dik } \\
\text { atif }\end{array}$ & $\begin{array}{c}\text { predi } \\
\text { katif }\end{array}$ & $\begin{array}{c}\text { predi } \\
\text { katif }\end{array}$ & $\begin{array}{c}\text { Fungs } \\
\text { ional }\end{array}$ \\
\hline \multicolumn{2}{|c|}{} & & & \\
\hline
\end{tabular}

Keterangan:

P1 : Proses berpikir predikatif

F1 : Proses berpikir fungsional

P11 : Melihat hubungan diantara dua konsep

P12 : Menyusun dan melengkapi situasi serta menentukan petunjuk

P13 : Berpikir tentang relasi, keputusan dan criteria

P14 : Mengidentifikasi variable

F11 : Menitikberatkan pada mata rantai cara melaksanakan keputusan

F12 :Menyusun dan membuat algoritma untuk bekerja

F13 : Berpikir tentang kegunaan dan bentuk kegiatan

F14 : Menganalisis bentuk

$\sqrt{ } \quad$ : Subjek memenuhi indikator

- $\quad$ : Subjek tidak memenuhi indikator

Berdasarkan table tersebut dapat disimpulkan bahwa proses berpikir mahasiswa subjek S1 dalam menyelesaikan soal-soal turunan fungsi cenderung tipe predikatif

b. Analisis sujek kedua

Table 2Proses berpikir subjek S2

\begin{tabular}{|c|c|c|c|c|c|}
\hline \multicolumn{2}{|c|}{} & \multicolumn{5}{c|}{ Nomor Soal } \\
\cline { 3 - 7 } \multicolumn{2}{c|}{} & 1 & 2 & 3 & 4 \\
\hline \multirow{4}{*}{ P1 } & P11 & $\sqrt{ }$ & - & - & - \\
\cline { 2 - 6 } & P12 & $\sqrt{ }$ & - & - & -- \\
\cline { 2 - 6 } & P13 & $\sqrt{ }$ & $\sqrt{ }$ & $\sqrt{ }$ & \\
\cline { 2 - 6 } & P14 & $\sqrt{ }$ & - & - & $\sqrt{ }$ \\
\hline \multirow{4}{*}{ F1 } & F11 & - & $\sqrt{ }$ & $\sqrt{ }$ & $\sqrt{ }$ \\
\cline { 2 - 6 } & F12 & - & $\sqrt{ }$ & $\sqrt{ }$ & $\sqrt{ }$ \\
\cline { 2 - 6 } & F13 & - & - & - & $\sqrt{ }$ \\
\cline { 2 - 6 } & F14 & - & $\sqrt{ }$ & $\sqrt{ }$ & - \\
\hline \multirow{2}{*}{$\begin{array}{c}\text { Kesimpu } \\
\text { lan }\end{array}$} & $\begin{array}{c}\text { Pre } \\
\text { dik } \\
\text { atif }\end{array}$ & $\begin{array}{c}\text { fungs } \\
\text { ional }\end{array}$ & $\begin{array}{c}\text { Fungs } \\
\text { ional }\end{array}$ & $\begin{array}{c}\text { Fungs } \\
\text { ional }\end{array}$ \\
\cline { 2 - 5 } & & & & \\
\hline
\end{tabular}

Keterangan:

P1 : Proses berpikir predikatif

F1 : Proses berpikir fungsionaL

P11: Melihat hubungan diantara dua konsep

P12:Menyusun dan melengkapi situasi serta menentukan petunjuk 
P13:Berpikir tentang relasi, keputusan dan criteria

P14: Mengidentifikasi variable

F11: Menitikberatkan pada mata rantai cara melaksanakan keputusan

F12:Menyusun dan membuat algoritma untuk bekerja

F13: Berpikir tentang kegunaan dan bentuk kegiatan

F14: Menganalisis bentuk

$\sqrt{ }$ : Subjek memenuhi indikator

- : Subjek tidak memenuhi indicator

Berdasarkan table diatas dapat disimpulkan bahwa proses berpikir mahasiswa subjek S2 dalam menyelesaikan soal-soal turunan fungsi cenderung tipe fungsional

c. Analisis suyek ketiga

Table 3 Proses berpikir subjek S3

\begin{tabular}{|c|c|c|c|c|c|}
\hline & \multicolumn{4}{|c|}{ Nomor Soal } \\
\hline & & 1 & 2 & 3 & 4 \\
\hline \multirow{4}{*}{$\begin{array}{l}P \\
1\end{array}$} & P11 & $\sqrt{ }$ & - & $\sqrt{ }$ & $\sqrt{ }$ \\
\hline & P12 & $\sqrt{ }$ & - & $\sqrt{ }$ & \\
\hline & P13 & $\sqrt{ }$ & $\sqrt{ }$ & $\sqrt{ }$ & $\sqrt{ }$ \\
\hline & P14 & $\sqrt{ }$ & - & $\sqrt{ }$ & $\sqrt{ }$ \\
\hline \multirow{4}{*}{$\begin{array}{l}F \\
1\end{array}$} & F11 & - & $\sqrt{ }$ & - & - \\
\hline & F12 & - & $\sqrt{ }$ & - & - \\
\hline & F13 & - & - & - & - \\
\hline & F14 & - & $\sqrt{ }$ & - & - \\
\hline \multicolumn{2}{|c|}{$\begin{array}{c}\text { Kesimp } \\
\text { ulan }\end{array}$} & $\begin{array}{l}\text { Predi } \\
\text { katif }\end{array}$ & $\begin{array}{c}\text { Fungsi } \\
\text { onal }\end{array}$ & $\begin{array}{l}\text { Predi } \\
\text { katif }\end{array}$ & $\begin{array}{l}\text { Predi } \\
\text { katif }\end{array}$ \\
\hline
\end{tabular}

Keterangan:
P1: Proses berpikir predikatif

F1:Proses berpikir fungsionaL

P11:Melihat hubungan diantara dua konsep

P12:Menyusun dan melengkapi situasi serta menentukan petunjuk

P13:Berpikir tentang relasi, keputusan dan criteria

P14: Mengidentifikasi variable

F11:Menitikberatkan pada mata rantai cara melaksanakan keputusan

F12:Menyusun dan membuat algoritma untuk bekerja

F13:Berpikir tentang kegunaan dan bentuk kegiatan

F14: Menganalisis bentuk

$\sqrt{ }$ : Subjek memenuhi indikator

-: Subjek tidak memenuhi indikator

Berdasarkan hasil tes di atas dapat disimpulkan bahwa proses berpikir mahasiswa subjek S3 dalam menyelesaikan soal-soal turunan fungsi adalah predikatif

d. Analisis subjek keempat

Table 4 Proses berpikir subjek S4

\begin{tabular}{|c|c|c|c|c|c|}
\hline & \multicolumn{4}{|c|}{ Nomor Soal } \\
\hline & & 1 & 2 & 3 & 4 \\
\hline \multirow{4}{*}{ P1 } & P11 & & & & $\sqrt{ }$ \\
\hline & P12 & $\mathrm{V}$ & & & \\
\hline & $\mathrm{P} 13$ & $\sqrt{ }$ & $\sqrt{ }$ & $\sqrt{ }$ & $\sqrt{ }$ \\
\hline & P14 & & & & $\sqrt{ }$ \\
\hline \multirow{4}{*}{$\mathrm{F} 1$} & F11 & $\sqrt{ }$ & $\sqrt{ }$ & $\sqrt{ }$ & \\
\hline & F12 & $\sqrt{ }$ & $\sqrt{ }$ & $\sqrt{ }$ & \\
\hline & F13 & & & & \\
\hline & F14 & $\sqrt{ }$ & $\sqrt{ }$ & $\sqrt{ }$ & \\
\hline \multicolumn{2}{|c|}{$\begin{array}{c}\text { Kesimpul } \\
\text { an }\end{array}$} & $\begin{array}{l}\mathrm{Fu} \\
\mathrm{ng} \\
\text { sio } \\
\text { nal }\end{array}$ & $\begin{array}{c}\text { Fungs } \\
\text { ional }\end{array}$ & $\begin{array}{c}\text { Fung } \\
\text { siona } \\
1\end{array}$ & $\begin{array}{l}\text { Predi } \\
\text { katif }\end{array}$ \\
\hline
\end{tabular}

Keterangan:

P1: Proses berpikir predikatif

F1: Proses berpikir fungsionaL

P11:Melihat hubungan diantara dua konsep

P12:Menyusun dan melengkapi situasi serta menentukan petunjuk 
P13:Berpikir tentang relasi, keputusan dan criteria

P14: Mengidentifikasi variable

F11:Menitikberatkan pada mata rantai cara melaksanakan keputusan

F12:Menyusun dan membuat algoritma untuk bekerja

F13:Berpikir tentang kegunaan dan bentuk kegiatan

F14: Menganalisis bentuk

$\sqrt{ }$ : Subjek memenuhi indikator

-: Subjek tidak memenuhi indicator

Berdasarkan hasil tes di atas dapat disimpulkan bahwa proses berpikir mahasiswa subjek S4 dalam menyelesaikan soal-soal turunan cenderung fungsional

Tabel 5 Rangkuman Proses Berpikir Subjek

\begin{tabular}{|c|c|c|}
\hline Kemampuan & $\begin{array}{c}\text { Kemampua } \\
\mathrm{n}\end{array}$ & $\begin{array}{c}\text { Kemampua } \\
\mathrm{n} \\
\text { Matematika }\end{array}$ \\
Kepribadian & & rendah \\
\hline Introvert & Predikatif & Fungsional \\
\hline Ekstrovert & Predikatif & Fungsional \\
\hline
\end{tabular}

\section{Diskusi}

Berdasarkan hasil penelitian yang telah dilakukan,mahasiswa yang memiliki kemampuan matematika yang tinggi cenderung berpikir predikatif dan mahasiswa yang yang memiliki kemampuan matematika yang rendah cenderung berpikir fungsional. Sedangkan kepribadian introvert atau ekstrovert ternyata tidak mempengaruhi kecenderungan proses berpikir baik tipe predikatif maupun fungsional. Hal ini kemungkinan diakibatkan pengambilan subjek yang terlalu sedikit yaitu empat orang. Selain itu hasil tes kepribadian cenderung menunjukan bahwa tidak ada seorang mahasiswa yang berkepribadian murni introvert saja ataupun ekstrovert saja Dalam kajian pustaka dijelaskan bahwa mahasiswa. pada umumnya mahasiswa yang berkepribadian introvert cenderung hati-hati dalam menyelesaikan soal dan mahasiswa berkepribadian ekstrovert cenderung tergesa-gesa dan ceroboh dalam mengerjakan soal. Pengecekan kepribadian mahasiswa yang hanya sekali saja mungkin mempengaruhi tipe kepribadian mahasiswa tersebut apakah introvert atau ekstrovert. Berdasarkan penelitian yang dilakukan oleh Triatri (2005), pada umumnya mahasiswa yang berkepribadian introvert memiliki kemampuan matematika yang tinggi dan mahasiswa yang berkepribadian ekstrovert memiliki kemampuan matematika yang rendah.

\section{SIMPULAN DAN SARAN}

\section{A. SIMPULAN}

Berdasarkan hasil analisis yang dilakukan terhadap subjek peneelitian, maka dapat disimpulkan proses berpikir dari masing-masing subjek adalah sebagai berikut:

1. Mahasiswa berkepribadian introvert yang memiliki kemampuan matematika tinggi dalam menyelesaikan soal-soal turunan fungsi mempunyai tipe proses berpikir predikatif

2. Mahasiswa berkepribadian introvert yang memiliki kemampuan matematika rendah dalam menyelesaikan soal-soal turunan fungsi mempunyai tipe proses berpikir fungsional

3. Mahasiswa berkepribadian ekstrovert yang memiliki kemampuan matematika tinggi dalam menyelesaikan soal-soal 
turunan fungsi mempunyai tipe proses berpikir predikatif

4. Mahasiswa berkepribadian ekstrovert yang memiliki kemampuan matematika rendah dalam menyelesaikan soal-soal turunan fungsi mempunyai tipe proses berpikir fungsional

B. SARAN

1. Bagi peneliti lain yang ingin mengadakan penelitian yang sejenis diharapkan dapat mengambil subjek yang lebih banyak dan soal yang lebih banyak pula sehingga dapat mengetahui proses berpikir dari masing-masing mahasiswa

2. Bagi dosen, dapat merancang model pengajaran yang lebih tepat yang disesuaikan dengan proses berpikir masing-masing mahasiswa sehingga diharapkan memperoleh hasil belajar yang maksimal atau lebih baik dari sebelumnya

\section{DAFTAR PUSTAKA}

Arikunto, Suharsimi.

1989.ManajemanPenelitian. P2LPTK

Azwar, Syaifudin. 1996. TesPrestasi:

FungsipengembangandanpengukuranPrest asiBelajar.PustakaBelajar.

Azisah, Try. 2008.

ProfilKemampuanSiswaSekolahMenengah PertamaDalamMemecahkanMasalahMate matika Open Ended.

Tesistidakdipublikasikan. UNESA

Hudoyo, Herman. 2003. Strategi Belajar Mengajar Matematika. Universitas Negeri Malang

Kersey, David. 1998. Please Understan Me. RinekaCipta: Jakarta

Laurens, Theresia. 2007. Metakognisi dan Hubungannya Dengan Tingkat Kesadaran berpikir. Makalah disajikan dalam Seminar Nasional Matematika. Bandung.

Marpaung, $\quad$ Y.1986. Proses berpikirSiswadalampembentukanKonsepAl goritmaMatematika. Yogyakarta: Pidato Dies Natalis XXXI IKIP SanataDarma

Moleong, Lexi.

MetodologiPenelitianKualitatif.

RemajaRosdaKarya. Bandung

Rahayu, $\quad$ Tri. 2004. ObservasidanWawancara. Bayumedia Publishing. Malang

Ratumanan, TanweyGersondanTheresia Laurens.2003. EvaluasiHasilBelajar yang RelevandenganKurikulumBerbasisKompet ensi.Surabaya:UnesaUniversity Press

Ratumanan,

2004.BelajardanPembelajaran. Surabaya: UnesaUniversity Press

Slameto, 1994. Belajar dan faktor-faktor yang Mempengaruhinya. Jakarta: Rineka Cipta

Syah, Muhibbin. 2003. Psikologi Pendidikan. Jakarta : Rineka Cipta

Sugiyono, Prof. 2008. Memahami Penelitian Kualitatif. C.V Alfabetha: Bandung.

Sunarto, Prof. 2001. Metodologi Penelitian. University Press. UNESA

Suryabrata, Sumadi. Psikologi Pendidikan. Jakarta: Rajawali Press.

www.mypersonality.comdiakses

Agustus 2015

www.duniapendidkanindonesia.comdiakse s 20 Agustus 2015

www.mbti.comdiaksespadatanggal

Agustus 2015

www.duniamatematika.comdiakses 